\title{
Business Sustainability of Local Consumption Products in Village Owned Enterprises from Gresik Regency, Indonesia
}

\author{
Vembri Aulia Rahmi*, Nanang Bagus Setiawan and Hadi Ismanto
}

\begin{abstract}
Department of Entrepreneurship, Faculty of Economy and Business, Universitas Muhammadiyah Gresik, Gresik, Indonesia * Corresponding author email: vembriaulia@umg.ac.id
\end{abstract}

\begin{abstract}
Various local products have been created, but the ability to support businesses and increase MSME income is not in accordance with the number of products presented in complementing Indonesian's government program "one village one product". Field studies show that Gresik Regency as an industrial city is strategically located and has an international port, and should experience an increase in the volume and value of exports. But it's just the opposite, there has been a significant decline. This research focuses on local consumption products of Village-Owned Enterprises (BUM Desa). The purpose of this research is to explore information about how local products can survive in competition and to describe the possibility of becoming competitive local products. The qualitative descriptive approach was chosen by the researcher as the method of this research by conducting in-depth interviews with the manager to analyze what business performance achievements have been. The findings proved that the sustainability of local product business is in a fluctuating position and there has been no significant increase in results, due to the weakness of human resources to develop product specificities, so it can be concluded that the sustainability of local product business is closely related to business managerial ability.
\end{abstract}

Keyword: local consumption product, business, sustainability, performance

\section{INTRODUCTION}

The implementation of the "One Village One Product (OVOP)" program in each country is carried out on various situations and objectives [1] [2] For Japan, OVOP was initiated with the aim of stimulating villages to produce unique and different products during a decline in population, while for Japan, OVOP was implemented to reduce poverty when the country's economy experienced a decline [1]In Indonesia, the movement is intended to support local wisdom of village potential and the role of UKM (Small and Medium Enterprises) [3] Local consumption products are expected to increase economic income from business activities. Previous studies have shown that many local consumption products are created, but not significantly increase marketing. The industrial revolution era 4.0 should be able to support a wider marketing process, because it supports big data access and networks. The local government of Gresik Regency opens opportunities to market local consumption products from village-owned companies, called Village-
Owned Enterprises or Cooperatives at the kelurahan level.

The large number of scattered SMEs also does not necessarily encourage high levels of exports and even tends to decline. It is undeniable that MSMEs have an important role for developing countries or in transitional periods, where when the country experiences an economic crisis, MSMEs are able to survive and support the economy by providing job opportunities. Gresik Regency export trade data shows a decline in exports in the last five years. Referring to Figure 1. it can be seen that the total export volume and export value continue to decline [4]. As it is known that Gresik Regency is a major industrial area with a strategic area close to the port as a transit point for trade, but why is the value of exports lower than import values. The village area in Gresik Regency is widespread, where there are 18 sub-districts and 330 villages with each village having superior products. The ability of local consumption products as a sustainable business field is a challenge in itself for rural business people facing the era of the industrial revolution 4.0. 


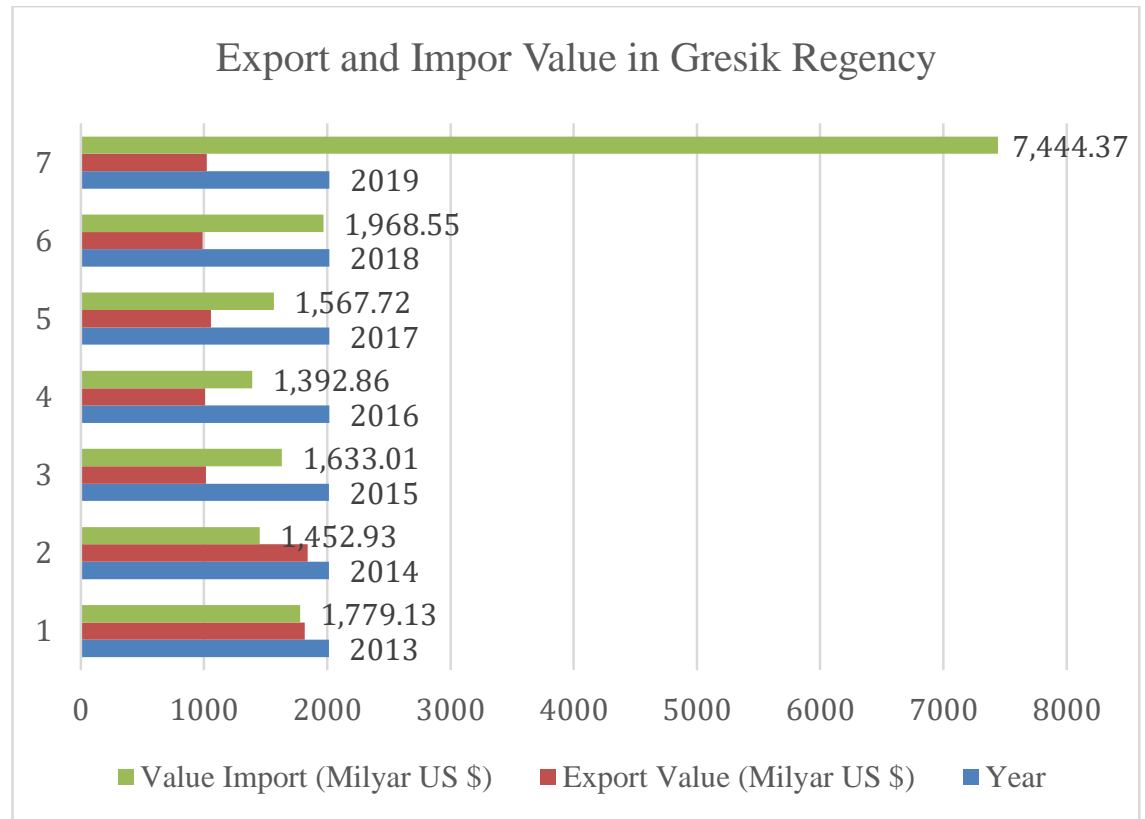

Source: BPS- Statistics of Gresik Regency, 2020

FIGURE 1. Expor and Impor Value in Gresik Regency

The focus of this research is to take the object of research on the product "red ginger" from Yosowilangun Village, from Village- Owned Enterprises (BUM Desa) "Cipta Sejahtera" in Manyar District and products from Kelurahan Ngipik in Kecamatan Manyar "Rosella" from the women's cooperative "Srikandhi Berbakti". The two villages were chosen as research objects because they are located close to urban areas and large industrial / manufacturing areas. The two villages are regions that receive corporate social funding assistance, namely "PT Petrokimia Gresik" and "PT Pertamina". This research is interesting, because many local consumption products are created by village-owned enterprises in Indonesia, but the business sustainability capability of their products has not progressed much [5].

It is not only the differentiation of local consumption products as a form of pride in the local wisdom of the village, but also raises a business sustainability strategy from local consumption products so that they can survive in the Era of the Industrial Revolution 4.0. The business challenge in the future is higher, because it faces a free market with many competitors from the same product quality. The business capability of local consumption products cannot be measured in just one or two years of business performance, but in the next few years it can be observed that the business of local consumption products can be called sustainable. A business is called successful if it experiences a high level of sustainability, where it is measured from the running time not from business skills and the ability to start a business of their own accord [6]. Thus, it is interesting to investigate this research and make the formulation of the problem to be explored as follows:

a. How do local consumption products place them as competitive local consumption products in the era of revolution 4.0?

b. How is the sustainability of the local consumption product business so that it can improve the performance of BUM Desa?

\section{METHODS}

This study uses a qualitative, exploratory, and descriptive research approach in observing and identifying the ability of local products to sustain business in the current era of the industrial revolution 4.0. The interpretive paradigm is used in this study by describing views and explanations of a condition. The focus of this research is to gather information on local products produced by business institutions at the village level. The purposive sampling method was used in this study with the criteria that the Village-Owned Enterprises selected as the object of the study were institutions that had 
local products that had been marketed for more than three years running. Researchers chose from three participants (A, B, C) from village commercial enterprises that have business products that have been established for approximately three years running. Participants in this study were the management of institutions: "Srikandi Berbakti" Women's Cooperative (as participant A), BUM Desa "Cipta Sejahtera" (as participant B), and BUM Desa "Podho Joyo" (as participant C,

Three participants were selected because they represented the management of Village-Owned Enterprises that had different characteristics of village products. Data were collected using semistructured interview guides based on literature [7]. Interviews were conducted during the period of one year mid-2019 to early 2020 with the three participants taking turns with an interview time of 60 - 90 minutes with the managers of Village-Owned Enterprises, especially directors and marketing staff. The research findings followed the data triangulation process, where the data reached a saturation point if the analysis from the additional interviews only led back to the mentioned aspects of the initial dialogue and did not produce any new findings. The results of the interviews with participants were then summarized and analyzed based on the information obtained. A summary containing information from research participants will be used as material for presenting the research results

\section{RESULTS}

\subsection{Description of Local consumption products as Competitive Local consumption products in the Revolutionary Era 4.0}

This research was conducted with the aim of finding out what factors most influence the local consumption product business to be underdeveloped and to explore information about the possibility of business sustainability for local consumption products. As well as understanding about the impact of local consumption product business on the performance of Village-Owned Enterprises. The evaluation of the local consumption product cycle is intended to determine the level of business sustainability of village commercial institutions, so that it can also be known about the business performance that has been achieved. Historical understanding of the creation of local consumption products will be described in this study from indepth interviews with participants.
The geographical location of Gresik Regency as an industrial city should really support the development of its local businesses, however the reality in the field shows that the level of sales of local consumption products has not been able to provide significant results on the income of business owners. The backgrounds for the creation of local consumption products in Gresik District have various situations. Based on the results of interviews with the managers of the "Srikandi Berbakti" Women's Cooperative (as participant A) and Participant B, as managers of BUM Desa "Cipta Sejahtera", it was stated that local consumption products were created as a form of institutional obligation because of the provision of CSR (Corporate Social Responsibility) funds from companies that have industrial locations adjacent to institutions. The two participants are managers of Village-Owned Enterprises, particularly the marketing managers of village commercial enterprises located in the middle of a city, but are included in the village administrative area group as well as the sub-district. Participant $\mathrm{C}$ as the manager of BUM Desa "Podho Joyo" and also the marketing manager explained that local consumption products were created to improve the welfare of the villagers. It is known that the BUM Desa "Podho Joyo" has a business location in the actual village area, namely a village location in a suburban area with village governance that upholds the value of local wisdom.

The three participants emphasized that the creation of local consumption products was created from government instructions on the "one village one product" program. The research findings show that the creativity of local consumption products has been proven by the variety of product types created. However, the results of observations by researchers in the field by adjusting the statistical data of Gresik Regency every year explain that there is no significant change in the business progress of Village-Owned Enterprises. It is evident from the quantity of sales of local consumption products that they are at a development point and only serve the local market. Even the local consumption product brands are still unable to show their strength in displaying the distinctive identity of the characteristic elements of the village name profile that is carried [6]. Imported products still dominate the local market in Gresik Regency, and export products are still led by industrial or manufactured products. Although the aspect of business sustainability can be viewed from the ability to strengthen the brand (branding), it does not 
guarantee that all product brands will achieve repositioning of the product.

Besides, the local consumption products in each region in Gresik Regency have different characteristics, but also have different product cycle rates. Participant A explained that the local consumption product produced by the "Srikandi Berbakti" Women's Cooperative is a health drink product called "rosella tea" and is at a development level. The product "rosella tea" has a brand name, and the business owner (village commercial institution) has also entered into business cooperation with other entrepreneurs. The product opinion response to Participant A is slightly different from the product opinion of Participant B, that both have the same type of product, but the local consumption product of the Village-Owned Enterprise "Cipta Sejahtera" is in an introductory position. Local consumption products in a maturity position were conveyed by the opinion of participant C (BUM Desa "Podho Joyo") [8], due to local consumption products already have an identity profile and are supported by the availability of an adequate marketing process. The own description of each local consumption product being the research sample indicates that there are still weaknesses in product management.

The era of revolution 4.0 brings changes to business processes and will affect the product management of Village-Owned Enterprises. In addition, disruption has also penetrated the business sector and has resulted in a shift in market tastes and needs. Local consumption products are expected to be able to adjust market interest, however, during the ongoing research, the observation of the three local consumption products being studied indicates that the three products have weaknesses in marketing. Local consumption products are products that are created and marketed by rural communities in their area. The use of the role of digital means has not been maximized, so the income received is still limited to cover operational costs and profits are small. Local consumption products should be competitive local consumption products in the global market for the "ASEAN Economic Community (AEC)". Proof of research results to Village-Owned Enterprises regarding local consumption products shows that there has been no achievement of achieving competition in local consumption products. The success of rural product business can be seen from the ability of small and medium enterprises in rural areas to increase exports, which usually occurs in developed countries, thus also demonstrating the success of business performance [9].

Local consumption products in Gresik Regency have not yet reached the stage as competitive local consumption products, which shows that the standard of quality products is a product differentiator and a characteristic of product excellence [10]. The views of the three participants confirmed that the product was made because of the encouragement of the local government in supporting the "one village one product" program. The uniqueness of local consumption products has not yet characterized the potential for superiority of local wisdom. The support of reliable human resources from the village is part of the obstacles for local consumption products to make local consumption products competitive. Weaknesses of human resources in the village include several limitations, such as: the number of personnel is insufficient for product management, the integrity of business actors and skills in business management are quite low, resulting in a decrease in enthusiasm for developing local consumption product businesses. Refers to .... Human resources are an important factor in the progress of a company, including Village-Owned Enterprises. Thus, product sales are in a volatile position and tend to decline in tune with the spirit of advancing local consumption product business.

\subsection{Local consumption product Business} Sustainability on Business Performance of Village-Owned Enterprises

Currently it is a challenge how to raise the position of the product from the development stage to the maturation stage with limited number of human resource personnel, while making changes from simple local consumption products to competitive local consumption products. Business theory states that business needs planning and change is eternal. The implementation of business and entrepreneurship concepts teaches that if the product is without a change process, it can result in business failure. Likewise for local consumption products without innovation, business sustainability is not achieved [11]. The success indicator of the business performance of Village-Owned Enterprises is seen from the ability of the local consumption product business to pass through each product positioning cycle, which is marked by the brand's ability to be recognized and remembered by customers. The determination of the success of business performance is influenced by the role of 
marketing in creating a strategy to penetrate the market.

Local consumption product business practices carried out by the three business institutions in this study indicate that marketing techniques are carried out by traditional methods of picking up the market (selling at store outlets). The use of digital platforms [12]in marketing methods for local consumption products has not been maximized, because human resources have not yet empowered digital tools. Consumers of local consumption products are local buyers in the Gresik Regency area, so the sustainability of the local consumption product business only meets local needs [13]. Thus, the sustainability of the local consumption product business does not have a significant influence on the progress of the business performance of Village-Owned Enterprises. The business performance of village-owned enterprises in the participant area in this study represents the business performance of micro, small and medium enterprises in Gresik regency. The findings of this study indicate that business performance tends to be relatively low and there has been no significant progress from micro, small and medium enterprises that are incorporated as business partners of VillageOwned Enterprises in Gresik Regency.

The performance indicators of micro, small and medium enterprises [14] are determined by the total production and the number of sales of local consumption products. Local consumption product business actors are worried about increasing the amount of production, while the market response of local consumption products in the district has not supported people's interest in local consumption of local consumption products, so it is very possible that there will be an accumulation of product supplies only. Research on the sustainability of local consumption product business if it is related to the performance of Village-Owned Enterprises, the focus of the discussion of the results of observations by researchers is to reveal how much the contribution of the role of local consumption product development to the performance of Village-Owned Enterprises. So far, according to participant A and participant B, it is stated that the contribution of local consumption products does not contribute to the business performance of village business institutions. A different opinion, according to participant $\mathrm{C}$ on local consumption products, stated that the sustainability of local consumption products, especially Sukorejo Village, has more potential to improve the business performance of VillageOwned Enterprises compared to the other two
(Ngipik and Yosowilangun Village) in the area of Gresik Regency.

\section{DISCUSSION}

Based on the exposure to research findings in the field, it is increasingly proving that the creation of local consumption products by the community is more influenced by driving factors by government programs with the theme of "one village one product" and weakens the influence of pull factors, such as increasing business contributions to VillageOwned Enterprises. The strength of the driving factor of the village community for entrepreneurship [15] is higher than the pull factor, which results in a weak motivation of human resources from village business institutions [16] Such a situation was obtained from the results of an interview with participant $\mathrm{A}$, who explained that if the ordering of local consumption products by consumers would be available if the order quantity was high, while the order and the quantity were a little less responsive and even rejected by the local consumption product producers. The level of awareness of Village-Owned Enterprises managers of the role of brands [17] in the sustainability of village businesses is still weak, so that often human resources are determined as an inhibiting factor for the success of village businesses.

Weaknesses in product management, especially in the field of product marketing due to weaknesses in the empowerment of digital devices by the managers of Village-Owned Enterprises should be immediately followed up to support product sustainability reaching the global market. The weakness of human resources in maintaining digital marketing program applications [18] is very possible if Village-Owned Enterprises seek to increase investment for their operations carried out privatization or handover to partners. It even allows for investment funding for Village-Owned Enterprises to involve collaboration with external parties such as large companies or industries. In addition, it is possible to collaborate with universities to support human resource issues [19] from the management of Village-Owned Enterprises. Thus the improvement in product management methods will further accelerate the improvement of local consumption products as competitive local consumption products in the era of revolution 4.0.

The sustainability of local consumption product business includes a series of stages of achieving a long process of business and requires innovation [20] and cooperation for all parties in 
Village-Owned Enterprises [10]. The business performance of Village-Owned Enterprises is built by creating business strength for local consumption products. Local consumption products should have the power to elevate local wisdom as a product characteristic. Business performance also illustrates how village business management can be managed appropriately by personnel who are worthy to lead a Village-Owned Enterprise. The development of the business performance of Village-Owned Enterprises requires managerial skills to bring local consumption products to the world export level, so that local consumption products can move up in class in the market. Experience and skills of local consumption product business managers, especially business directors, will improve the sustainability of local consumption product businesses, thereby strengthening the business performance of VillageOwned Enterprises. The ability of local consumption products to maintain product quality indirectly reflects how sustainable the local consumption products are. Meanwhile, the business performance of Village-Owned Enterprises will follow the achievement of business sustainability for local consumption products.

\section{CONCLUSION}

The creation of various local consumption products for the purpose of business is not just the ability to create product advantages as a characteristic of village identity, but more important than this is the ability of village human resources to maintain products as a business sustainability for the welfare of rural communities. The sustainability of local consumption products following the development of the 4.0 industrial revolution era is the ability of local consumption products to create change as competitive local consumption products. Achieving the business performance of Village-Owned Enterprises requires a gradual achievement process, both in terms of product management, but also proficiency in business managerial for the managers of village business institutions.

\section{REFERENCES}

[1] Natsuda K Igusa K Wiboonpongse A and Thoburn J, 2012 One village one product Rural development strategy in Asia: The case of OTOP in Thailand Can. J. Dev. Stud. 33, 3 p. 369-385.

[2] Phonsuwan $\mathrm{S}$ and Kachitvichyanukul V, 2011 Management system models to support decision-making for micro and small business of rural enterprise in Thailand in
Procedia Engineering.

[3] Triharini M Larasati D and Susanto R, 2014 Pendekatan One Village One Product (OVOP) untuk Mengembangkan Potensi Kerajinan Daerah Studi Kasus: Kerajinan Gerabah di Kecamatan Plered, Kabupaten Purwakarta ITB J. Vis. Art Des. 6, 1 p. 2942.

[4] BPS Statistics of Gresik Regency, 2020 Gresik Regency in Figures 2020 .

[5] Arifin B et al., 2020 Village fund, villageowned-enterprises, and employment: Evidence from Indonesia J. Rural Stud. 79 p. 382-394.

[6] Sejjaaka S Mindra R and Nsereko I, 2015 Leadership Traits and Business Sustainability in Ugandan SMEs: A Qualitative Analysis Int. J. Manag. Sci. Bus. Adm.

[7] Gómez-Galán J Lázaro-Pérez C MartínezLópez J Á and López-Meneses E, 2020 Measurement of the MOOC phenomenon by pre-service teachers: A descriptive case study Educ. Sci.

[8] Efendi K N and MARUF M F, 2019 PERAN BADAN USAHA MILIK DESA (BUMDESA PODHO JOYO) SEBAGAI LEMBAGA EKONOMI DESA DI DESA SUKOREJO KECAMATAN SIDAYU KABUPATEN ... Publika 7, 2.

[9] Phillipson J Tiwasing P Gorton M Maioli S Newbery R and Turner R, 2019 Shining a spotlight on small rural businesses: How does their performance compare with urban? J. Rural Stud. 68 p. 230-239.

[10] Dyllick T and Rost Z, 2017 Towards true product sustainability J. Clean. Prod. 162 p. 346-360.

[11] Luqmani A Leach M and Jesson D, 2017 Factors behind sustainable business innovation: The case of a global carpet manufacturing company Environ. Innov. Soc. Transitions 24 p. 94-105.

[12] Aulia Rahmi V Ismanto H and Zainuddin Fathoni M, 2020 Inovatif Saat Pandemi Covid Melalui Pelatihan Kewirausahaan Khas Perempuan Berbahan Sampah "Kolaborasi BUMDes dan Warga" Din. J. Pengabdi. Kpd. Masy.

[13] Zhou Q Gao P and Chimhowu A, 2019 ICTs in the transformation of rural enterprises in China: A multi-layer perspective Technol. Forecast. Soc. Change 145 p. 12-23.

[14] Ye S Xiao H and Zhou L, 2019 Small 
accommodation business growth in rural areas: Effects on guest experience and financial performance Int. J. Hosp. Manag. 76 p. 29-38.

[15] Galvão A R Mascarenhas C Marques C S E Braga V and Ferreira M, 2020 Mentoring entrepreneurship in a rural territory - A qualitative exploration of an entrepreneurship program for rural areas $J$. Rural Stud. 78 p. 314-324.

[16] Pak K Kooij D T A M De Lange A H and Van Veldhoven M J P M, 2019 Human Resource Management and the ability, motivation and opportunity to continue working: A review of quantitative studies Hum. Resour. Manag. Rev. 29, 3 p. 336-352.

[17] Escribano M Gaspar P and Mesias F J, 2020 Creating market opportunities in rural areas through the development of a brand that conveys sustainable and environmental values J. Rural Stud.

[18] Räisänen J and Tuovinen T, 2020 Digital innovations in rural micro-enterprises $J$. Rural Stud. 73 p. 56-67.

[19] Barraket J Eversole R Luke B and Barth S, 2019 Resourcefulness of locally-oriented social enterprises: Implications for rural community development J. Rural Stud. 70 p. 188-197.

[20] Yin X Chen J and Li J, 2019 Rural innovation system: Revitalize the countryside for a sustainable development $J$. Rural Stud. 